\title{
Analysis Twitter's as Tools a Political Campaigns For New Party during the 2020 Regional Head Election in Indonesia
}

\author{
Dimas Subekti ${ }^{1 *}$, Zuly Qodir ${ }^{2}$ \\ ${ }^{1}$ Master of Government Affairs and Administration, Universitas Muhammadiyah Yogyakarta, Indonesia \\ ${ }^{2}$ Master of Government Affairs and Administration, Jusuf Kalla School of Government, Universitas \\ Muhammadiyah Yogyakarta, Indonesia \\ *Corresponding author: dsubekti05@gmail.com
}

\begin{abstract}
.
The Perindo Party and the Gelora Party are new participants in the political arena in Indonesia. Still, both can show their existence in the 2020 regional election. Therefore, this study aims to determine how the Perindo Party and the Gelora Party use Twitter as a tool for the 2020 regional election political campaign. This research method uses NVIVO 12 plus analyzing data with chart analysis, cluster analysis, and word cloud analysis. The data source for this research came from the Twitter accounts of the Perindo Party and the Gelora Party. The reason for choosing the Twitter social media accounts of the Perindo Party and the Gelora Party is because these parties are new participants in Indonesian politics who can show their existence in political contestation. The findings show that Perindo and Gelora parties use Twitter social media optimally for political campaigns in the 2020 regional head elections. The political campaign narrative of the Perindo Party and the Gelora Party on Twitter is related to the names of parties and political party actors. The Perindo Party is dominant in political campaign content such as party activities, party ideas, relations with the public, the issue of COVID-19, and the Party's vision and mission. On the other hand, the Gelora Party excels in the content of its Party's slogan campaign. The intensity of the Gelora Party's political campaign on Twitter is higher than that of the Perindo Party in 2020.
\end{abstract}

Keywords: Twitter, Political Campaigns, Perindo Party, Gelora Party, Regional Election

\section{Introduction}

This study aims to determine how the Perindo Party and the Gelora Party use Twitter social media as a political campaign tool in the 2020 regional election. The two political parties have similar origins; the Perindo Party and the Gelora Party were community organizations before becoming political parties. The Gelora Party was founded on October 28, 2019, by former high-ranking Prosperous Justice Party (PKS) Anis Matta and Fahri Hamzah. The aim of both of them establishing the Gelora Party was none other than a form of disappointment with the Prosperous Justice Party (PKS) for having eliminated them. The Indonesian People's Wave Party (Gelora) is a transformation of the community organization of the Indonesian New Direction Movement (Garbi)(Adhitia, 2020). Meanwhile, the Perindo 
Party was declared a political party on February 7, 2015, at the Jakarta International Expo, Kemayoran, Jakarta, by MNC Group boss Hary Tanoesoedibjo(T. H. Putri, 2019).

The reason for taking this research topic is that the Perindo Party and the Gelora Party are new participants in the political arena. Still, both can show their existence in Indonesian political contestation. The Perindo Party received the highest votes than the three new political parties participating in the 2019 general election. The votes were acquired by the four new political parties participating in the 2019 elections in figure 1.

Figure 1: The results of the vote acquisition of four new political parties participating in the 2019 election

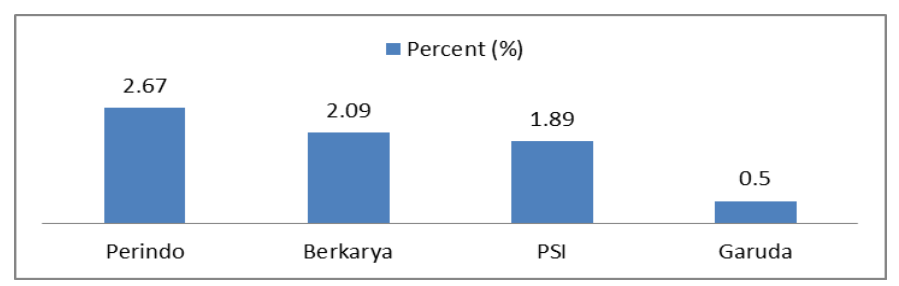

Source: The general election commission of the Republic of Indonesia (2019)

The Perindo party won 2.67percent of the votes, Berkarya had 2.09 percent of the votes, PSI received 1.89percent of the votes, and finally Garuda with 0.5 percent of the valid votes. Even though the vote acquisition could not lead the Perindo Party to enter the parliament because it did not pass the parliamentary threshold, it can prove that Perindo is a new political party that can compete with the other three parties in Indonesian politics. Furthermore, in the 2020 regional elections, the Perindo Party provided letters of support to 210 regional head candidate pairs at the governor, mayor, and regent levels. The Secretary-General of the central leadership board Perindo Party, Ahmad Rofiq, said 130 pairs of regional heads supported by the Perindo party won(Sunusi, 2020). Meanwhile, the Indonesian Gelora Party could also help the regional leader win the 2020 regional head election. The Gelora Indonesia Party is one of the supporters of regional head candidate pairs in the 2020 regional elections, even though they do not have the legal status to carry a candidate because they do not have a parliament seat. The regional head elections were held in 270 regions covering nine provinces, 37 cities, and 224 regencies. The Gelora Party has provided 205 Decrees in support of candidate pairs for regional heads of the governor, the mayor, and regent level. Based on the National Leadership Council data, 117 teams of regional leaders supported by the Gelora Party won 57 percent (Sulistiyono, 2020).

The importance of this research is that as a new political party, the Perindo Party and the Gelora Party must compare the names of parties to recognize them. During the Covid-19 pandemic, which limits movement activities and mass crowds, the Indonesian Gelora Party must strive to be widely known by the public(Kaslam, 2020). More than that, the two political parties must also carry out political campaigns to participate in the 2020 regional elections. Twitter social media can be a facility for political parties to carry out political campaigns. Social media Twitter can be used for mutual communication, interaction, and conveying information to the Indonesian people. Twitter has established itself as one of the most popular online activities and one of the most effective channels of communication and information sources(Mansour, 2018). Social media Twitter are platforms for communication. The platform allows people in a shared network to interact, share content, and collaborate 
online(David, 2017). Twitter serves as a platform for people of common interests to connect and share information openly and transparently. Twitter's most significant advantage is that it allows for unlimited interaction and communication worldwide(Kuźniar \& Szopiński, 2016).

Some previous research is related to the use of social media for political campaigns. In the 2016 U.S. presidential election, Trump and Clinton used social media as a campaign tool. Clinton posted more posts on Facebook and Twitter the week before the election. Trump was present on social media long before the election(Davis, 2017). The use of social media as a campaign platform was critical in the 2008 U.S. presidential election, with some saying that Barack Obama's use of social media helped him win(John Allen Hendricks and Robert Denton, Jr Lanham, 2010). The 2013 German federal election campaign shows that politicians use Facebook and Twitter to communicate with specific characteristics of society and the sociotechnical environment(Stier, Bleier, Lietz, \& Strohmaier, 2018). During the Spanish national election campaign in November 2011, it was found that political parties still tend to use Twitter as a one-way communication tool(Pablo Arago'n, Karolin Eva Kappler, Andreas Kaltenbrunner, David Laniado, 2013). In Indonesia, social media is also used by candidates in facing elections. Joko Widodo used social media Twitter for political branding as a form of political campaigning in the 2012 election for Jakarta governor (Sandra, 2013). There is even a political buzzer in political campaign activities on Twitter social media. A professional political buzzer's role is to carry out attacks by criticizing candidate pairs or other political actors.

Meanwhile, political volunteers' buzz on social media conveys information on social media based on personal initiatives based on shared ideology(Felicia \& Loisa, 2019). In the 2017 DKI Jakarta regional head election, social media was used for black campaigns to attack candidates. The three candidates who participated in the 2017 Jakarta gubernatorial election were all hit. Black messages with nuances of political campaigns circulate in cyberspace through social media(Saleh, 2018).

Several previous studies have focused more on candidates who use social media for political campaigns. Therefore, the novelty in this study focuses on the use of social media Twitter as a campaign tool for new political parties. This research will answer questions about how the Perindo Party and the Gelora Party use Twitter social media for political campaigns during the 2020 regional head elections in Indonesia.

\section{Literature Review}

\subsection{Political Campaign in Social Media}

In a country that adopts a democratic system, political campaigns are significant in introducing candidates to the public. Political campaigns are understood as organized efforts that seek to influence the decision-making process in certain groups. Therefore, each candidate must consider careful strategy and planning(Fatimah, 2018). A political campaign is an act of doctrine aimed at gaining support. Campaign efforts can be carried out individually or in organized people to achieve a decision-making process within a group, and campaigns can also be carried out to influence, obstruct, distort achievement(Nur, 2019). The 
overarching goal of political campaigns is to increase the likelihood of victory. To that end, any aspect of a campaign is assessed in terms of its potential to win(Nickerson \& Rogers, 2014). According to Hafied Cangara (2009), political campaign planning goes through three phases: the organizing and testing phases and the critical phase(Damayanti \& Hamzah, 2017). The political campaign has several models. Leon Ostergaard developed the Ostergaard campaign model. The Five Functional Stages Development campaign model and Nowak and Warneryd's campaign model are examples of traditional campaign models(Hariyani, 2015).

Social media has changed the ways of the political campaign to win their candidates. The media has been prepared for disseminating the vision and mission of political candidates since social media has been a promising strategy campaign(Ulfa, Purnomo, \& Kasiwi, 2020). Social networking sites like Twitter and Facebook are attractive to politicians. Political candidates use networking sites to encourage group formation and maintain solid networks for political campaigns(Bor, 2014). In a political context, social media is becoming more prevalent. Social media platforms like Facebook and Twitter are thought to have the ability to increase political engagement more recently. Twitter is an excellent platform for users to disseminate general information and political opinions publicly through networks of political institutions such as politicians, political parties, and political foundations(Stieglitz \& DangXuan, 2013). Social media must be planned, communicated, and programmed to increase the credibility of political campaigns. Organizational communication, in this case, political parties, is an important consideration to ensure adequate interaction on social media platforms(Ardha, 2014).

Digital technologies such as social media allow candidates, political parties, and other interest groups to take advantage of significant breakthroughs in data-driven political campaign techniques(Chester \& Montgomery, 2017). Political parties have created digital media techniques for political campaigns, allowing them to reach out to voters more personally. Websites have evolved into social media hotspots where voters can be engaged before, during, and after elections. The parties' outreach to voters continues between elections, primarily through regular email, social media, and text communications to supporters, reinvigorating the parties' electoral role(Owen, 2014).

\subsection{Political Parties}

According to Thomas Madison, a political party is a group of people, either a majority or a minority of the total population, which are organized and guided by the same desires or interests, which are harmful to the rights of other citizens or the community's long-term interests(Ebeling, 2016). According to Jimly Asshiddiqie, the word party has a broad and narrow meaning. In a broad sense, a party is a grouping of people in an organization in general that is not limited to political organizations. Meanwhile, a party is a political party in a narrow sense, a community organization engaged in politics(Muhadam \& Teguh, 2015). Friedrich defines a political party as a group of organized people who are organized stably to seize or maintain control of the government for their Party's leadership and, based on this control, giving their party members ideal and material benefits(Imam Yudhi Prasetya, 2011). Meanwhile, according to Sigmund Neumann, political parties are organizations of political activists trying to control government power and win popular support through competition with other groups or groups with different views(Budiardjo, 2015). 
Political parties are formally organized groupings whose members share common goals, objectives, and ideals. The goal is to achieve political power and influence, mainly by using constitutional methods to carry out their ideas(Pasaribu, 2017). Political parties are a reflection of a democratic state which is believed to be a prerequisite for modern state life. Regardless of which interests and by whom, it is clear that political parties are institutions channeling interests, channeling the interests of the people and those of the authorities(Rosana, 2012). Political parties are commonly regarded as democratic agents who perform various tasks, including policy formation, interest aggregation and articulation, social integration, and elite recruiting(Osei, 2013). Political parties, as stated by Hague and Harrop, have several functions. Among these are articulation and aggregation, which are functions to formulate interests. At the same time, the various interests contained in groups that have the same thing are combined into one. The role of political communication is directed at bridging the government and society. The function of political socialization is required at the process in which a person gets his views and orientation towards the values and norms in society. Political recruitment is a way for parties to seek or get new members by inviting them, especially people who have the ability in politics and leadership to participate in politics(Hanafi, 2014).

\section{Research Method}

This type of research is qualitative, using NVIVO 12 plus in analyzing data. The features used in NVIVO 12 plus to analyze data are chart analysis and word cloud analysis. The data source of this research comes from the Twitter social media accounts of the Perindo Party and the Gelora Party. The reason for choosing the Twitter social media accounts of the Perindo Party and the Gelora Party is because these parties are new participants in Indonesian politics who can show their existence in political contestation. The period for data collection ranges from the beginning of 2020 and the end of 2020. This is because, during that period, the 2020 regional head election stages were carried out. Therefore, data were taken from the social media accounts of the Perindo Party and the Gelora Party in the form of followers, following, tweets, retweets, political campaign narratives, political campaign content, actors who play a role in and the intensity of political campaigns.

The Perindo Party Twiter social media account has 23,000 followers and 130 following. The number of tweets on the social media accounts of the Perindo Party Twitter was 3154, and the number of retweets was 95. The Gelora Party Twitter social media account has 10,000 followers and 72 following. Meanwhile, the number of tweets on the social media Twitter for the Gelora party was 2713 and had several retweets of 493. Following, tweet, and retweet the Twitter social media accounts of the Perindo Party and the Indonesian Gelora Party shows that the Twitter social media account is actively used. 


\author{
Stockholm, Sweden
}

\title{
4. Result and Discussion
}

\subsection{Political Campaign Narrative}

Political campaigns as one of the critical series in the electoral process. Political Campaigns become a space for eligible participants to convince voters by offering their vision, mission, programs, and self-image. Social media can become a compelling new space for election participants, including political parties, to publicize campaign narratives (Perdana \& Wildianti, 2019). The Perindo Party and the Indonesian Gelora Party used Twitter social media to spread political campaign narratives. Word Cloud Analysis in NVIVO Plus 12 is used to view the campaign narrative of the Perindo Party and the Gelora Party. Figure 2 shows the conversation's narrative on the Twitter social media accounts of the Perindo Party and the Indonesian Gelora Party during the 2020 simultaneous regional head elections. Some of the words that are often discussed are "perindo", "partai", "perindoupdate", "indonesia", "gelora", \#geloraindonesia, \# pilkada2020, "pilkada", @harytanoe, @fahrihamzah, \#gelorakansangatindonesia, \#perindopeduli, and other.

Figure 2: Political Campaign Narrative the Gelora Party and the Perindo Party on Twitter

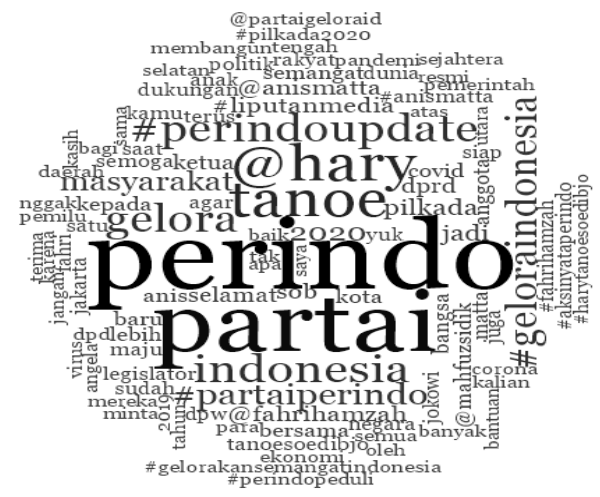

Source: Word Cloud NVIVO plus 12

Figure 2 shows The Perindo Party and the Gelora Party consistently discussed the narrative of political campaigns to compare their party names with the words "perindo," "gelora," "Partaiperindo," and \#geloraindonesia. The Perindo Party and the Indonesian Gelora Party also discussed the "pilkada2020", "pilkada" as a form of narrative for the political campaign of their participation in the 2020 simultaneous regional head elections. The Perindo Party and the Indonesian Gelora Party also mentioned @fahrihamzah, @harytanoe, @animatta, and @ mahfuzsidik as a form of introduction to the Party's founders and administrators. In addition, the Perindo Party and the Indonesian Gelora Party mentioned the narrative of the political campaign \#gelorakansangatindonesia and "indonesiasejahtera," which were the Party's slogans. The two political parties also discussed the issue of "covid," "virus," and "corona" as a form of concern for the COVID-19 pandemic that has hit Indonesia. Interestingly, the 
Perindo Party is actively issuing campaign narratives that care for people affected by COVID-19 with \#perindopeduli and \#aksinyataperindo.

\subsection{Political Campaign Content}

Social media can directly connect public institutions with the community in real-time. A public organization uses social media as a communication tool by creating content for the public to know(Mergel, 2016). For example, the Perindo Party and the Indonesian Gelora Party made political content on Twitter social media as a form of political campaign for their participation in the 2020 regional head elections. The chart analysis in figure 3 helps to understand the content of the political movement of the Perindo Party and the Gelora Party during the 2020 regional election. The political campaign content of the two parties is related to the activities of political parties, political party ideas, relations with the public, the issue of COVID-19, the slogans of political parties, and the vision and mission of political parties.

Figure 3: Political Campaign Content of the Gelora Party and the Perindo Party on Twitter

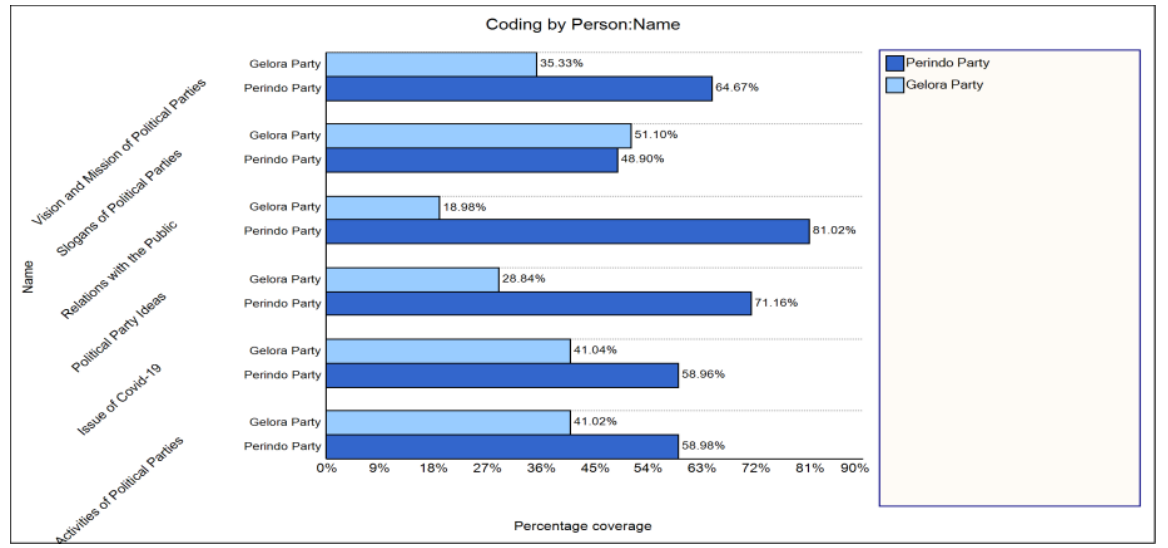

Source: Chart Analysis NVIVO Plus 12

Figure 3 shows Political campaign content about political Party activities; the Perindo Party has 58.98percent while the Gelora Party is only 41.02 percent. Political campaign content about the ideas of political parties, the Indonesian Gelora Party was only 28.84 percent, and the Perindo Party was 71.16percent. Perindo Party has a high percentage of political campaign relations with the public, amounting to 81.02percent, while the Gelora Party is only 18.98\%. Furthermore, the content on the COVID-19 issue, the Perindo Party, presented 58.96 percent and the Gelora Party of 41.04 percent. The Perindo Party focuses on community economic issues due to the COVID-19 pandemic. The Perindo Party uses economic issues as a way to get people's attention. The issues raised by Perindo refer to the Party's central vision, namely economic prosperity(Ken Bimo Sultoni, n.d.). One of them is the Perindo Party 
moving by assisting orphanages affected by COVID-19(Aky, 2021). The Gelora Party also discussed the issue of COVID-19. According to the chairman of the Gelora Party, Anis Matta, COVID-19 cannot be predicted when it will end, and the Coronavirus pandemic is also a trigger for world political battles. The world is undergoing a rearrangement. In history, every large-scale rearrangement like this will always be accompanied by geopolitical actions (Saputra, 2020). One of the Gelora Party Twitter social media accounts' tweets featured Anis Matta's words about COVID-19. Tweet content, namely "we need a strong social network to fix the crisis."

The slogans for political parties, the Perindo Party, are 49.90 percent, and the Indonesian Gelora Party is 51.10percent. The Gelora Party Tweet on Twitter about the content of the political Party's slogan, namely "let's together, we gelora the spirit of the nation's children by continuing to collaborate with the Gelora Party." One of the tweets from the Perindo Party regarding the content of the political Party's slogan is "community welfare and regional development, Indonesia is faster to advance." Political campaign content is related to the vision and mission of political parties; the Perindo Party is 64.67 percent, while the Gelora Party is only $35.33 \%$. One of the Gelora Party Twitter tweets about its vision and mission is that "the creative economy will be one of the waves to bring Indonesia to become the world's 5th power". The Perindo Party also tweeted about its vision and mission on Twitter, namely "Perindo will continue to fight for the welfare of farmers in Indonesia".

\subsection{Political Campaign Intensity}

The intensity of the Perindo Party's political campaign using Twitter social media in JanuaryMarch 2020 was the highest at 657. In April-June 2020, the intensity of the Perindo Party's political campaign was 282 , experiencing a decrease from the previous three months. In mid2020 , to be precise, in July-September, the intensity of his political campaign was 182, down again from before. Interestingly, in October-December 2020, the power of political campaigns on Twitter was only 104. Even though in that month, the 2020 regional head election campaign stages had been carried out. The campaign period for the 2020 regional head elections starts from September 26 to December 5, 2020. Figure 4 shows the complete results of the intensity of the Perindo Party political campaign on Twitter social media.

Figure 4: Political Campaigns Intensity Perindo Party based on Twitter

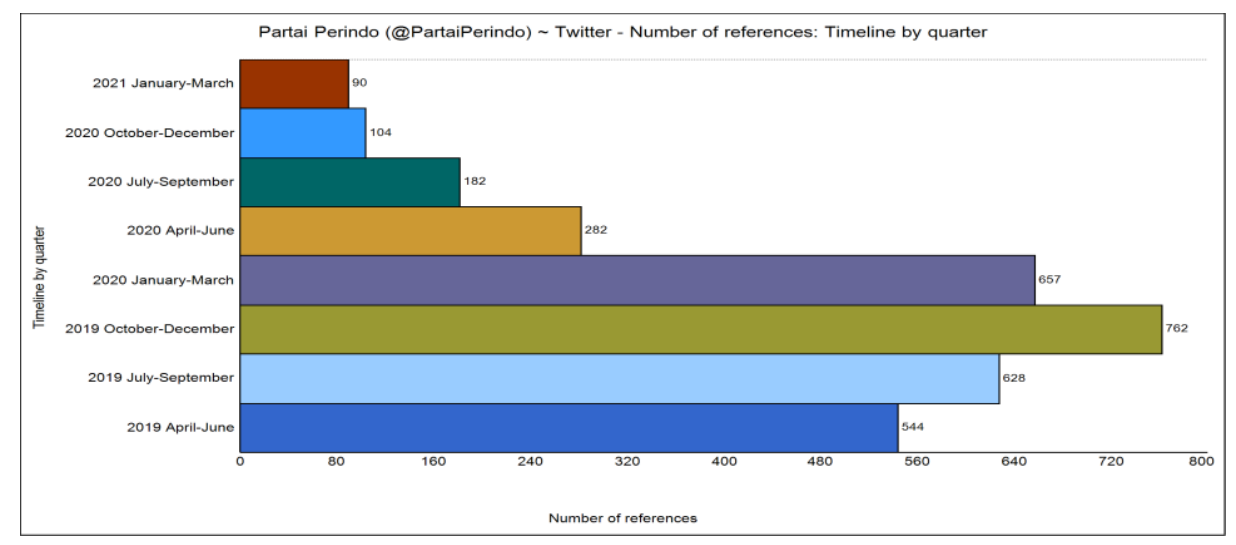

Source: Social Media the Perindo Party 
Figure 4 shows the intensity of the Perindo Party's political campaign on Twitter in 2020 is less high than in 2019. In 2019 the Perindo Party also participated in the legislative and presidential elections. The 2019 General Election is the inaugural event for the Perindo Party in the Indonesian political contestation. The Perindo Party was the first Party to register and received the serial number 9(R. S. Putri, 2018). n the October-December 2020 period, the intensity of the Perindo Party campaign on Twitter was quite massive. The ranks of the central leadership of the Perindo Party instructed all party machines, starting from the levels of the board, cadres, to sympathizers in districts/cities holding mobile elections and fighting their best for the victory of the regional head candidate pairs supported by the Perindo Party(Sarasa, 2020).

Meanwhile, the intensity of the Gelora Party's political campaign on Twitter social media during the 2020 regional elections was massive. In January-March 2020, it was 71, increased rapidly in April-June 448, and decreased slightly in July-September 2020, namely by 440. Figure 5 shows the intensity of the Gelora Party's political campaign on Twitter.

Figure 5: Political Campaigns Intensity the Gelora Party based on Twitter

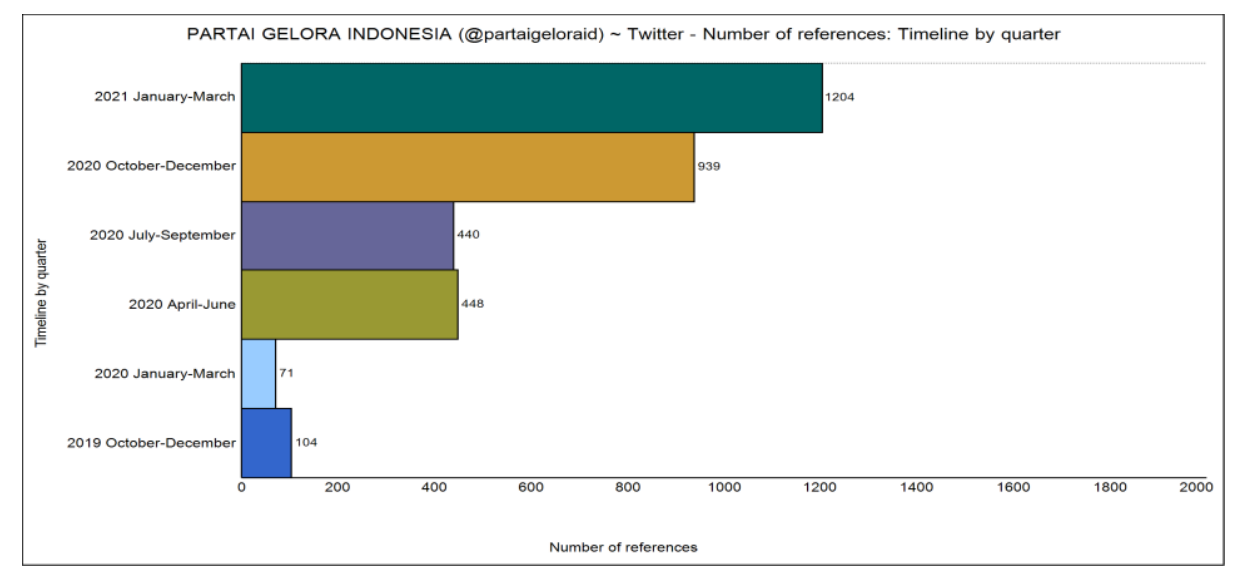

Source: Social Media Twitter the Gelora Party

Figure 5 shows the campaign period for simultaneous regional head elections in 2020, the intensity of the political campaign in October-December 2020; the Gelora Party was massive with 939. The Gelora Party tried to introduce its Party by supporting many candidate pairs in the 2020 simultaneous regional head elections. Instruction from the chairman General Gelora Party to party cadres and administrators to win the supported candidate pairs seriously. Anis Matta also said that the Gelora Party was a party that was born from a crisis, with the spirit of a famous wave. This Party is expected to be the pioneer of a new awakening by presenting regional leaders who are capable of being the pioneers of the national awakening(Kirom, 2020)

\section{Conclusion}

The conclusions in this study are, first, Perindo and Gelora parties use Twitter social media optimally for political campaigns in the 2020 regional head elections. Second, the narrative of the political campaign of the Perindo Party and the Gelora Party on Twitter in the 
2020 regional head elections related to the names of parties and political party actors. Third, the Perindo Party is dominant in political campaign content such as political party activities, political party ideas, relations with the public, the issue of COVID-19, and the Party's vision and mission. Meanwhile, the Gelora Party excels in campaign content for political party slogans on Twitter social media. Fourth, the intensity of the Gelora Party's political campaign was high in October-December 2020 because that time was the implementation of the stages of the 2020 regional head election campaign period. Meanwhile, the intensity of the Perindo Party's political campaign in 2020 was lower than in 2019, and this was due to its first participation in the contested politics of legislative general election and the 2019 presidential election.

The limitation in this study is the period for collecting data from the Twitter social media accounts of the Perindo Party and the Gelora Party, which is only in 2020. Therefore, the recommendation for further research is the data collection period from 2019 because, in that year, the Perindo Party was the first to follow Indonesia's political contestation.

\section{Acknowledgment}

This paper is the output of the government ethics course

\section{References}

Adhitia, F. B. (2020). 5 Tokoh Ini Bikin Parpol Baru karena Kecewa dengan Partai Lama. Retrieved March 26, 2020, from INDTIMES website: https://www.idntimes.com/news/indonesia/fitang-adhitia/5-tokoh-ini-bikin-parpol-barukarena-kecewa-dengan-partai-lama

Aky. (2021). Partai Perindo Salurkan Bantuan ke Panti Asuhan yang Terdampak Pandemi Covid-19. Retrieved March 29, 2021, from Okezone.com website: https://news.okezone.com/read/2021/02/18/519/2364505/partai-perindo-salurkanbantuan-ke-panti-asuhan-yang-terdampak-pandemi-covid-19? page $=2$

Ardha, B. (2014). Social Media sebagai media kampanye partai politik 2014 di Indonesia. Visi Komunikasi, 13(1), 105-120.

Bor, S. E. (2014). Using Social Network Sites to Improve Communication Between Political Campaigns and Citizens in the 2012 Election. American Behavioral Scientist, 58(9), 1195-1213. https://doi.org/10.1177/0002764213490698

Budiardjo, M. (2015). Dasar-Dasar Ilmu Politik (Edisi Revi). PT Gramedia Pustaka Utama.

Chester, J., \& Montgomery, K. C. (2017). The role of digital marketing in political campaigns. Internet Policy Review, 6(4), 0-20. https://doi.org/10.14763/2017.4.773

Damayanti, N., \& Hamzah, R. E. (2017). Strategi Kampanye Politik Pasangan Jokowi-Jk Pada Politik Pemilihan Presiden 2014. WACANA, Jurnal Ilmiah Ilmu Komunikasi, 16(2), 279. https://doi.org/10.32509/wacana.v16i2.52

David, C. C. (2017). Social Media Use by Frontline Government Agencies: Review and 
July $23-25,2021$

\author{
Stockholm, Sweden
}

Recommendations. Public Policy, 50-72.

Davis, J. (2017). Presidential Campaigns and Social Networks : How Clinton and Trump Used Facebook and Twitter During the 2016 Election. Dominican Scholar.

Ebeling, M. (2016). Epistemic political egalitarianism, political parties, and conciliatory democracy. Political Theory, 44(5), 629-656. https://doi.org/10.1177/0090591715605352

Fatimah, S. (2018). Kampanye sebagai Komunikasi Politik: Esensi dan Strategi dalam Pemilu. Resolusi, 1(1), 5-16. Retrieved from https://ojs.unsiq.ac.id/index.php/resolusi/article/view/154

Felicia, F., \& Loisa, R. (2019). Peran Buzzer Politik dalam Aktivitas Kampanye di Media Sosial Twitter. Koneksi, 2(2), 352. https://doi.org/10.24912/kn.v2i2.3906

Hanafi, R. I. (2014). Pemilihan Langsung Kepala Daerah di Indonesia: Beberapa Catatan Kritis Untuk Partai Politik. Jurnal Penelitian Politik, 11(2), 1-16. Retrieved from http://ejournal.politik.lipi.go.id/index.php/jpp/article/view/197

Hariyani. (2015). Model Kampanye Pilkada Atasi Politik Uang Dan Sikap Pesimis Pemilih (Telaah Teoritis dan Konsep Implementasinya). Jurnal Ilmiah Komunikasi, 6(1), 31-45. https://doi.org/http://dx.doi.org/10.30659/jikm.6.1.31-45

Imam Yudhi Prasetya. (2011). Pergeseran Peran Ideologi Dalam Partai Politik. Jurnal Ilmu Politik Dan Ilmu Pemerintahan, 1(1), 1-11.

John Allen Hendricks and Robert Denton, Jr Lanham, M. (2010). Communicator-in-Chief: How Barack Obama Used New Media Technology to Win the White House by John Allen Hendricks, Robert Denton and Review by : Sharon E . Jarvis Source : Presidential Studies Quarterly, Vol . 40 , No . 4 ( D. Presidential Studies Quarterly, 40(4), 800-802.

Kaslam, K. S. (2020). Strategi Komunikasi Politik Partai Gelora Sulawesi Selatan di Masa Pandemi Covid-19. VOX POPULI, 3(2), 118-132.

Ken Bimo Sultoni, P. H. (n.d.). Media Dan Politik: Strategi Kampanye Partai Perindo Dan Psi Dalam Mempengaruhi Suara Pemilih Di Kota Semarang. Ejournal3.Undip.Ac.Id. Retrieved from https://ejournal3.undip.ac.id/index.php/jpgs/article/view/27293

Kirom. (2020). Dukung 200 Calon Kepala Daerah di Pilkada 2020, Cara Partai Gelora Dikenal Publik. Retrieved March 29, 2021, from Merdeka.com website: https://www.merdeka.com/politik/dukung-200-calon-kepala-daerah-di-pilkada-2020cara-partai-gelora-dikenal-publik.html

Kuźniar, W., \& Szopiński, W. (2016). The Use of Social Media by Local Government Units to Communicate with Stakeholders. Nierówności Społeczne a Wzrost Gospodarczy, 45(1), 247-254. https://doi.org/10.15584/nsawg.2016.1.25

Mansour, E. (2018). The adoption and use of social media as a source of information by Egyptian government journalists. Journal of Librarianship and Information Science, 50(1), 48-67. https://doi.org/10.1177/0961000616669977 
July $23-25,2021$

\author{
Stockholm, Sweden
}

Mergel, I. (2016). Social media institutionalization in the U.S. federal government. Government Information Quarterly, 33(1), 142-148. https://doi.org/10.1016/j.giq.2015.09.002

Muhadam, L., \& Teguh, I. (2015). Partai Politik Dan Sistem Pemilihan Umum Di Indonesia. In PT Raja GRafinso Persada (Vol. 1).

Nickerson, D. W., \& Rogers, T. (2014). Political campaigns and big data. Journal of Economic Perspectives, 28(2), 51-74. https://doi.org/10.1257/jep.28.2.51

Nur, E. (2019). The Communication Strategy of Success Team in Political Campaign to Win Legislative Candidates in Makassar. Jurnal Diakom, 2(1), 120-128.

Osei, A. (2013). Political parties in Ghana: Agents of democracy? Journal of Contemporary African Studies, 31(4), 543-563. https://doi.org/10.1080/02589001.2013.839227

Owen, D. (2014). New Media and Political Campaigns. The Oxford Handbook of Political Communication, (October 2019), 1-22. https://doi.org/10.1093/oxfordhb/9780199793471.013.016

Pablo Aragón, Karolin Eva Kappler, Andreas Kaltenbrunner, David Laniado, Y. V. (2013). Communication Dynamics in Twitter During Political Campaigns: The Case of the 2011 Spanish National Election. Policy and Internet, 55(3), 509-516. https://doi.org/10.2307/3503380

Pasaribu, P. (2017). Peranan Partai Politik dalam Melaksanakan Pendidikan Politik The Role of Political Parties In Conducting Political Education. JPPUMA: Jurnal Ilmu Pemerintahan Dan Sosial Politik, 5(1), 51-59.

Perdana, A., \& Wildianti, D. (2019). Narasi Kampanye dan Media Sosial dalam Pemilu Presiden dan Wakil Presiden Tahun 2019 Aditya Perdana dan Delia Wildianti. Jurnal Bawaslu DKI Jakarta, (February), 19-37.

Putri, R. S. (2018). Empat Partai Baru di Pemilu 2019 dan Kekuatan Pendirinya. Retrieved March 29, 2021, from Tempo.com website: https://nasional.tempo.co/read/1062006/empat-partai-baru-di-pemilu-2019-dankekuatan-pendirinya/full\&view=ok

Putri, T. H. (2019). Perindo, Partai Baru Peserta Pemilu 2019. Retrieved March 28, 2021, from IDN Times website: https://www.idntimes.com/news/indonesia/teatrika/mengenalperindo-partai-baru-peserta-pemilu-1/3

Rosana, E. (2012). Politik Partai Politik dan Pembangunan. Jurnal Teropong Aspirasi Politik Islam, 8 .

Saleh, G. (2018). Kampanye Hitam Pilgub DKI 2017: Analisis Wacana van Dijk pada Meme di Media Sosial. Jurnal Studi Komunikasi (Indonesian Journal of Communications Studies), 2(3), 322. https://doi.org/10.25139/jsk.v2i3.827

Sandra, L. J. (2013). Political Branding Jokowi Selama Masa Kampanye Pemilu Gubernur Dki Jakarta 2012 Di Media Sosial Twitter. Jurnal E-Komunikasi, 1(2), 276-287. Retrieved from http://studentjournal.petra.ac.id/index.php/ilmu- 
komunikasi/article/view/912

Saputra, M. G. (2020). Ketum Gelora Nilai Krisis Akibat Pandemi Covid-19 akan Berlangsung Lama. Retrieved March 29, 2021, from Merdeka.com website: https://www.merdeka.com/politik/ketum-gelora-nilai-krisis-akibat-pandemi-covid-19akan-berlangsung-lama.html

Sarasa, A. B. (2020). Sukseskan Pilkada Serentak 2020, Perindo Jabar Panaskan Mesin Partai. Retrieved March 29, 2021, from Okezone.com website: https://news.okezone.com/read/2020/11/14/525/2309536/sukseskan-pilkada-serentak2020-perindo-jabar-panaskan-mesin-partai

Stieglitz, S., \& Dang-Xuan, L. (2013). Social media and political communication: a social media analytics framework. Social Network Analysis and Mining, 3(4), 1277-1291. https://doi.org/10.1007/s13278-012-0079-3

Stier, S., Bleier, A., Lietz, H., \& Strohmaier, M. (2018). Election Campaigning on Social Media: Politicians, Audiences, and the Mediation of Political Communication on Facebook and Twitter. Political Communication, 35(1), 50-74. https://doi.org/10.1080/10584609.2017.1334728

Sulistiyono, S. T. (2020). Partai Gelora Sebut 117 Pasangan Calon Kepala Daerah yang Didukung Menang Pilkada 2020. Retrieved March 26, 2020, from Tribunnews.com website: https://www.tribunnews.com/pilkada-2020/2020/12/10/partai-gelora-sebut-117pasangan-calon-kepala-daerah-yang-didukung-menang-pilkada-2020

Sunusi, M. (2020). 4 Pasangan Calon Jagoan Perindo di Pilkada Sulsel Menang. Retrieved March 3, 2021, from Okezone.com website: https://makassar.sindonews.com/read/272720/710/4-pasangan-calon-jagoan-perindo-dipilkada-sulsel-menang-1608275541

Ulfa, K., Purnomo, E. P., \& Kasiwi, A. N. (2020). The Campaign Strategy of 2019 Presidential and Vice-Presidential Elections on Social Media. Society, 8(2), 284-297. https://doi.org/10.33019/society.v8i2.137 